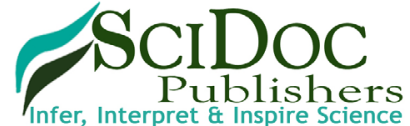

International Journal of Clinical Therapeutics and Diagnosis (IJCTD)

ISSN: 2332-2926

\title{
Bioactive Evaluation and Antioxidant Potential of Three Native Fruits of the Pampa Biome: Yellow Araçá (Psidium Cattleyanum), Big River Cherry (Eugenia Involucrata) and Jaboticaba (Plinia Cauli- fora). Perspectives for the Prevention of Damage in Biomolecules, Caused by Oxidative Stress
}

Research Article

\author{
Passos, BTS ${ }^{1}$, Lemos MRB ${ }^{1 *}$, Helbig E $E^{1}$, Zambiazi RC ${ }^{2}$, Otero ${ }^{3}$, Lemos $\mathrm{PE}^{4}$, Moraes RMJ ${ }^{1}$, Priebe VS
}

${ }^{1}$ Universidade Federal de Pelotas, Faculty of Nutrition, Nutrition Department, street Gomes Carneiro 1, Pelotas RS Brazil.

${ }^{2}$ Chemical, Pharmaceutical and Food Sciences Center, Universidade Federal de Pelotas, POB 354, Pelotas RS Brazil.

Postgraduate Program in Seed Science and Technology, Universidade Federal de Pelotas, POB 354, Pelotas RS Brazil.

${ }^{4}$ Universidade Federal de Pelotas, Engineering Center, Computer Engineering, Street Gomes Carneiro 1, Pelotas RS Brazil.

\section{Abstract}

There is a great variety of Biomes in Brasil with valuable medicinal potential. The typical fruits, tropical, subtropical and of diverse climate, constitute a promising scenario for the control and prevention of numerous pathologies. Recent studies suggest that extracts from certain fruits can signal positive effects through their natural antioxidants, in the defense mechanisms against reactive oxygen species (ROS) and in the diseases caused by them. The present study evaluated three fruits of the Pampa Biome, originating in the south of Rio Grande do Sul, Brazil: yellow Araça (Psidium cattleyanum), Big River Cherry (Eugenia involucrata) and Jaboticaba (Plinia cauliflora), segregated in pulp and peel. The contents of vitamin C, phenolic compounds, carotenoids and anthocyanins were evaluated. The antioxidant activity was determined by the capture of the 2,2'-azinobis (3-ethylbenzothiazoline-6-sulfonic acid) - ABTS radical in aqueous and ethanolic extracts. All analyzes were performed in triplicates and submitted to the Tukey test $-\mathrm{p}<.05-$ ANOVA. The moisture content of the fruits was greater than $75 \%$, and ${ }^{\circ}$ Brix of $11.40 \pm 0.08 ; 9.40 \pm 0.36$ and $12.90 \pm 0.08$, respectively for Yellow araçá, Big River cherry and Jaboticaba. The highest antioxidant activity was observed in the ethanolic extracts of the peel of Jaboticaba and Yellow araçá; and in the aqueous extracts of the peel of the yellow Araçá, peel and pulp of the Rio Grande cherry and the Jaboticaba. The highest acidity content was observed in the peel and pulp of Jaboticaba, and the highest vitamin $\mathrm{C}$ content was observed in the yellow Araçá pulp and in the peel of the Big River cherry. The content of phenolic compounds and anthocyanins were prominent in the peel of Jaboticaba. The highest flavonoid content was observed in the yellow Araçá pulp and in the Jaboticaba peel. Chlorophyll content was prominent in the peel of the Big River cherry and Jaboticaba. The carotenoid content did not stand out in the portions of the fruits studied. It is concluded that the native fruits demonstrate potential in the ability to assist in the protection of the organism by the inhibition of free radicals due to the presence of natural antioxidants, both in the pulp and in the peel.

Keywords: Pampa Biome; Native Fruits; Antioxidant Activity; Oxidative Stress.

\section{Introduction}

Studies show that the consumption of fruits and vegetables is related to the prevention of chronic diseases, probably due to the increase in the consumption of antioxidant compounds contained therein [1]. The main need of cells and tissues is to protect themselves against oxidative stress, being extremely important for the immune system, where the levels of the aggressive agents are controlled by the antioxidant defense system, which is composed of antioxidants and pro-antioxidants [1].

Hippocrates (460 b.C - 377 a.C) - considered the father of western medicine - among his statements already emphasized that food, when chosen and ingested, in a healthy way, represented the basis of life. In his famous phrase: "Be your food your medicine" and, "Be your medicine your food", reproduced that the use of them

\footnotetext{
*Corresponding Author:

Lemos MRB,

Universidade Federal de Pelotas, Faculty of Nutrition, Nutrition Department, Street Gomes Carneiro 1, Pelotas RS Brazil, 96010-610.

E-mail: rebonilla@gmail.com
}

Received: December 11, 2019

Accepted: January 17, 2020

Published: January 21, 2020

Citation: Passos, BTS, Lemos MRB, Helbig E, Zambiazi RC, Otero D, Lemos PE, et al., Bioactive Evaluation and Antioxidant Potential of Three Native Fruits of the Pampa Biome: Yellow Araçá (Psidium Cattleyanum), Big River Cherry (Eugenia Involucrata) and Jaboticaba (Plinia Cauliflora). Perspectives for the Prevention of Damage in Biomolecules, Caused by Oxidative Stress. Int J Clin Ther Diagn. 2020;S1:02:001:1-7. doi: http://dx.doi.org/10.19070/2332-2926-SI02-01001

Copyright: Lemos MRB $^{\circ}$ 2020. This is an open-access article distributed under the terms of the Creative Commons Attribution License, which permits unrestricted use, distribution and reproduction in any medium, provided the original author and source are credited. 
as sources of healing and well-being, if before it was clear, came to be considered beyond the beliefs of the "common sense", also, as prevention and assistance in the promotion of integral health [2], perceptible, since then, that science recognizes in food, a determinant factor for the prevention of diseases [3-5].

In this context, the search for a balanced life has been a constant, from the beginning, extending to the contemporary society, finding, from natural sources, the active compounds, able to maintain the homeostasis of the organism and guarantee the protection against diverse illness, making feeding their own medicine. These determinants amplify the interest of the pharmaceutical industry for the diversity contained in the Brazilian Biomes, a vast still unexplored patrimony and with native plant species, threatened with extinction even before being discovered by science [1, 4]. The importance of these compounds found in nature is based on the presence of phytochemicals, which are compounds with potential antioxidant action against biomolecule damage caused by oxidative stress $[2,3,5]$. The production of ROS's (Reactive Oxygen Species) in the body comes from inherent reactions to life, including breathing, metabolic changes and energy production in the intracellular environment. These reactive species, while free and in excess, cause imbalance, triggering oxidative stress, one of the precursors of NCCD - non-communicable chronic diseases (cancer, coronary diseases, heart diseases, cerebrovascular accident-stroke-CAS, arterial hypertension, premature aging and other degenerative processes involved in this process) [6, 8-10].

Native fruits, such as Araçá yellow (Psidium cattleyanum), Big River Cherry (Eugenia involucrata) and Jaboticaba (Plinia cauliflora), due to the characteristics they present, are a probable protective source of the biological material against ROS $[1,4-6]$.

Biome Pampa cultivars are still poorly explored, but they deserve attention on the part of researchers, as recent studies point to a "peculiar potential, due to their specificities, with emphasis on nutritional characteristics, being rich in vitamins, anthocyanins, antioxidants, minerals and many other other bioactive compounds " $[1,5,8]$.

While some of these compounds act as free radical scavengers, others act as metal chelators, catalyzing reaction reactions to generate reactive oxygen species - $\operatorname{ROS}[9,10]$. Thus, there is a large field with potential to be explored for the insertion of new species into productive systems. Rare, however, are the studies that assess the actual antioxidant potential of regional foods as well as the bioavailability of nutrients and possible antinutritional components.

Considering the importance of the preservation of plant species, together with the stimulus for a healthy diet, with peculiar characteristics and probable beneficial actions to health, this study sought to evaluate the properties of the native fruits of the southern region of the country, through the fractions of bark and pulp with emphasis on the profile of bioactive substances.

\section{Experimental Part}

The study was carried out in vitro, with samples courtesy of Embrapa Clima Temperado, located in the County of Pelotas /

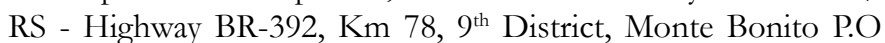

BOX 403, ZIP: 96010-971.

\section{Materials and Methods}

\section{Materials}

Variations of the fruits of Araçá yellow (Psidium cattleyanum), Big River Cherry (Eugenia involucrata) and Jaboticaba (Plinia cauliflora), harvested at the ideal point of maturation at harvest time, were obtained from the southern region of Brazil. Rio Grande do Sul, from the cultivars of Embrapa Clima Temperado, for the analysis and elaboration of this study.

\section{Methods}

Pulp and peel of Araçá yellow (Psidium cattleyanum), Big River Cherry (Eugenia involucrata) and Jaboticaba (Plinia cauliflora), were collected in the months of the harvest, at the stage of commercial maturation, selected from the firmness of the fruits and characteristic coloring. After this step, the healthy fruits were washed with running water, dried at room temperature and stored at $\pm-17^{\circ} \mathrm{C}$ (standard freezer), individually, in polyethylene packages. Afterwards, they were transported in thermal boxes, isolated and placed in ultra-freezer, with temperature of $-85^{\circ} \mathrm{C}$, for further analysis.

Then the fruits were thawed at room temperature, separated into the pulp and bark fractions, initiating the experimental studies.

\section{Determination of Macronutrients}

The content of water, ashes, proteins, total sugars and lipids was determined according to the Analytical Chemistry Association (AOAC): Official Methods of Analysis. Washington (USA) [11], with some modifications.

\section{Determination of Degrees Brix}

The ${ }^{\circ}$ Brix reading was performed in triplicate, using an electronic refractometer, using a drop of the juice of each fruit.

\section{Determination of Color}

The color was evaluated objectively by the color space reflectance, using Minolta CR-300 colorimeter, with standard illuminant D65 and angle of observation of $2^{\circ}$, following the methodology of Hunterlab, 1996 [12].

The readings were performed in triplicate at different points of the fruits and, afterwards, the average of these values was performed.

\section{Determination of Phenolic Compounds}

For the determination of phenolic compounds of fruit samples, the Folin-Ciocalteu method (Alves; Kubota, 2013) [13] was used, with minor modifications. $0.5 \mathrm{ml}$ of the samples were collected and then mixed with $2.5 \mathrm{ml}$ of $0.2 \mathrm{~N}$ reagent and after 5 minutes $2 \mathrm{ml}$ of sodium carbonate solution $(7.5 \%)$ was added. After incubation at room temperature in the dark for $2 \mathrm{~h}$, the absorbance was measured at $725 \mathrm{~nm}$ in a spectrophotometer (JENWAY 6705 
UV / Vis). The standard curve with gallic acid at concentrations of 30 to $500 \mu \mathrm{g} \cdot \mathrm{mL}^{-1}$ was used as the calibration curve. The results were expressed in $\mathrm{mg}$ equivalent of gallic acid per $100 \mathrm{~g}$ of dry matter (mg EAG.100g ${ }^{-1}$ ).

\section{Determination of Carotenoids}

The total carotenoid content was determined according to the methodology described by Rodriguez-Amaya (2001) [14]. The readings were performed at the absorbances of $450 \mathrm{~nm}$ ( $\beta$-carotene), $445 \mathrm{~nm}$ ( $\alpha$-carotene), $449 \mathrm{~nm}$ (zeaxanthin) and 470 $\mathrm{nm}$ (lycopene).

Quantifications were performed through Equation 1 and the results expressed in milligrams per $100 \mathrm{~g}$ of dry matter.

Carotenoids $\left(\mu \mathrm{g} \cdot \mathrm{g}^{-1}\right)=\left(\right.$ Absorbance $\mathrm{x}$ extract volume $(\mathrm{mL}) \times 10^{6}$ / Absorption coefficient x 100 x sample weight (g)) ---- Eq (1)

\section{Determination of Anthocyanins}

Anthocyanin content was determined according to the method described by Francis (1982) [15]. $1 \mathrm{~g}$ of sample was suspended in $10 \mathrm{~mL}$ of extraction solution $(1.5 \mathrm{~N} \mathrm{HCl}$ in $85 \%$ ethanol) in $50 \mathrm{~mL}$ Falcon tube. It was homogenized for $2 \mathrm{~min}$ in vortex and the volume was made up to $50 \mathrm{ml}$ with the extractive solution. It was left in the dark and refrigerated for 12 hours. After filtering on whatman \# 1 filter paper, $1000 \mu \mathrm{L}$ of the filtrate was placed in a $10 \mathrm{~mL}$ flask. The absorbance readings were carried out at $535 \mathrm{~nm}$ and $374 \mathrm{~nm}$, and the calculation was done by equation 1 :

Anthocyanin content $=($ ABS $\mathrm{x}$ dilution factor $) \times 1000 /$ Sample weight x Absorption coefficient ---- (eq.1)

ABS $=535 \mathrm{~nm}$; absorption coefficient $=982(\mathrm{~g} / 100 \mathrm{~mL})-1 . \mathrm{Cm}-1$.

\section{Determination of Flavonoids}

The total content of flavonoids was determined using the method of Funari and Ferro (2006) [16], with few modifications. The volume of $500 \mu \mathrm{l}$ of $2 \%$ aluminum chloride in methanol was mixed with the same volume of the sample solution $(100 \mu \mathrm{L}$ of extract for $50 \mathrm{~mL}$ of distilled water). The reading was made at 425 $\mathrm{nm}$, the total flavonoid content being determined using a standard quercetin curve. The results were expressed in terms of milligram equivalents of quercetin per 100 grams of dry matter (mg EQ $\left.100 \mathrm{~g}^{-1}\right)$.

\section{Chlorophylls}

$1 \mathrm{~g}$ samples were added to $5 \mathrm{~mL}$ of $80 \%$ (v/v) acetone. The material was centrifuged at $3000 \mathrm{rpm}$ for $15 \mathrm{~min}$ and the supernatant was transferred to a $25 \mathrm{ml}$ volumetric flask, which was quenched with $80 \%(\mathrm{v} / \mathrm{v})$ acetone. Absorbance of extract was obtained by spectrophotometry at 647 and $663 \mathrm{~nm}$, Ultrospec 2,000 UV/ Visible equipment (Pharmacia Biotech), was quenched with 80\% acetone. The total chlorophyll content, ' $a$ ' and ' $b$ ' were calculated through Equations 2, 3 and 4, established by Lichtenthaler (1987) [17]. The results were expressed in milligrams per $g$ of dry matter.

Chl total $=7,15\left(\mathrm{~A}_{663}\right)+18,71\left(\mathrm{~A}_{647}\right)-----(2)$

$C_{b l} a^{\prime}=12,25\left(A_{663}\right)-2,79\left(A_{647}\right)----(3)$
$C b l^{\prime} b^{\prime}=21,50\left(A_{663}\right)-5,10\left(A_{647}\right)-----(4)$

\section{Determination of antioxidant activity}

The antioxidant activity by ABTS was determined by the ability of the compounds present in the samples to sequester the ABTS (2,2'-azino-bis (3-ethylbenzthiazoline-6-sulfonic acid) radical according to Re et al., 18 (1999) [18], with modifications, for which $2 \mathrm{~g}$ of the sample were weighed in Falcon tube, to which $20 \mathrm{ml}$ of methanol was added. After mixing was homogenized using an Ultra-Turrax, followed by storage for $24 \mathrm{~h}$ under stirring and water bath at $25^{\circ} \mathrm{C}$. After the extract was filtered with cotton and stored in amber glass under refrigeration.

A solution of ABTS was prepared, where $5 \mathrm{~mL}$ of $7 \mathrm{mM}$ ABTS and $88 \mathrm{~mL}$ of $140 \mathrm{mM}$ potassium sulfate were added, the mixture was maintained at dark, at room temperature for 16h. Then, $1 \mathrm{~mL}$ of the mixture was diluted in methanol to obtain the absorbance of $1.410 \pm 0.010$ at $734 \mathrm{~nm}$.

For the quantification of the antioxidant activity, $100 \mu \mathrm{L}$ of the sample extract was added to $3.9 \mathrm{~mL}$ of ABTS solution, then the mixture was homogenized using an Ultra-Turrax. The sample was read in UV/Visible Ultrospec 2.000 spectrophotometer (Pharmacia Biotech) after 6 min of reaction, at a wavelength of $734 \mathrm{~nm}$.

Free radical scavenging activity was determined by comparison with a standard Trolox (5,7,8-tetramethylchromane-2-carboxylic acid) curve, and the results expressed in $\mu$ molTEAC. $g^{-1}$ sample, the antioxidant capacity being equivalent to Trolox relative.

\section{Determination of acidity}

The titratable acidity was determined by potentiometric volumetry, indicated for dark or heavily colored samples. Samples were diluted in water and homogenized, then the $\mathrm{pH}$ was determined in bench $\mathrm{pH}$ meter previously calibrated with buffer solutions $\mathrm{pH} 4.0$ and 10.0. The solutions were titrated with $0.1 \mathrm{M}$ sodium hydroxide to a $\mathrm{pH}$ range (8.2-8.4), according to the method 311/ IV of the Instituto Adolfo Lutz (2008) [19]. Results were expressed as \%.

\section{Vitamin C Detection}

The content of Vitamin $\mathrm{C}$ was determined by the method described by Zambiazi (2010) [20]. For this, fruit juice was extracted, filtered and the quantification of ascorbic acid (vitamin C) was performed by titration, using standard solution of iodine and sodium thiosulphate and starch solution as indicator. The results were determined by equation 1 , expressing the results in $\mathrm{mg}$ of ascorbic acid. $100 \mathrm{~mL}^{-1}$ of juice.

Vit $C=\left(V_{1} \times F_{1}\right)-\left(V_{2} \times F_{2}\right)----($ Equation 1)

Where: $\mathrm{V} 1=$ Volume of iodine spent in titration

$\mathrm{V} 2=$ Volume of thiosulfate spent in titration

$\mathrm{F}=$ solution correction factor

\section{Statistical Analyzes}

For the analysis of the obtained results was used ANOVA analysis 
of variance, followed by the statistical test of Tukey, considering as level of statistical significance, the limit of $5 \%$.

\section{Results and Discussion}

\section{Centesimal Composition}

According to the presented results, it is observed that the fruits are constituted by high moisture content, expected fact, since they are species that have high concentration of water [20]. Table 1 shows the respective data for the centesimal composition of the samples studied, according to the shell and pulp. It is noteworthy that the bark of the cherry-of-rio-grande has a higher protein content, while the yellow arapa pulp, the higher carbohydrate concentration, which corroborates with Vanin's studies [18], which found a value of $14,43 \pm 5.21$ for carbohydrates in the whole fruit of the yellow araçá.

\section{Evaluation of antioxidant potential}

Some of the evaluated portions of the fruit obtained results with significant differences regarding their potential of antioxidant activity by the ABTS method. In addition, an oscillation in fruit results is observed regarding the type of extraction to which it was submitted, as can be observed in Table 2.

The samples that presented the highest antioxidant potential

Table 1. Centesimal composition of the fruit portions $\left(\mathrm{g} \cdot 100 \mathrm{~g}^{-1}\right)$

\begin{tabular}{|c|c|c|c|c|c|}
\hline$\%$ & Moisure & Extrat Ethereal & Proteín & Ashes & Carbohydrates \\
\hline AS & $80.03 \pm 0.02$ & $0.13 \pm 0.01$ & $1.02 \pm 0.35$ & $0.73 \pm 0.01$ & $18.09 \pm 0.40$ \\
\hline AP & $76.27 \pm 0.06$ & $0.073 \pm 0.01$ & $1.16 \pm 0.38$ & $0.080 \pm 0.01$ & $22.42 \pm 0.45$ \\
\hline CS & $84.55 \pm 0.28$ & $0.53 \pm 0.01$ & $4.34 \pm 0.11$ & $0.13 \pm 0.13$ & $10.45 \pm 0.52$ \\
\hline CP & $84.38 \pm 0.45$ & $0.04 \pm 0.01$ & $2.60 \pm 0.27$ & $0.46 \pm 0.17$ & $12.52 \pm 0.56$ \\
\hline JS & $82.35 \pm 0.02$ & $0.04 \pm 0.01$ & $2.63 \pm 0.27$ & $0.38 \pm 0.049$ & $14.60 \pm 0.33$ \\
\hline JP & $87.91 \pm 0.11$ & $0.03 \pm 0.03$ & $1.97 \pm 0.22$ & $0.25 \pm 0.060$ & $9.84 \pm 0.08$ \\
\hline
\end{tabular}

AS = Yellow Araçá shell; AP = Yellow Araçá Pulp; CS = Big River Cherry Shell; CP = Big River Cherry Pulp; JS = Jaboticaba Shell; JP = Jaboticaba Pulp.

Table 2. Antioxidant activity of fruit peel and pulp, in aqueous and ethanolic extract, expressed as percentage of ABTS radical inhibition.

\begin{tabular}{|c|c|c|}
\hline \multicolumn{3}{|c|}{ Antioxidant Activity - ABTS } \\
\hline & Aqueous Extract & Etanolic Extract \\
\hline AS & $74.58735 \pm 11.99269^{\mathrm{a}, \mathrm{b}}$ & $99.59259 \pm 0.183946^{\mathrm{a}}$ \\
\hline AP & $62.116 \pm 21,47996^{\mathrm{b}}$ & $45.62963 \pm 2.796726^{\mathrm{c}}$ \\
\hline CS & $99.18615 \pm 0.329039^{\mathrm{a}}$ & $65.65432 \pm 2.891947^{\mathrm{b}}$ \\
\hline CP & $64.77533 \pm 3.476675^{\mathrm{a}, \mathrm{b}}$ & $47.33333 \pm 1.392054^{\mathrm{c}}$ \\
\hline JS & $99.33517 \pm 0.218091^{\mathrm{a}}$ & $99.24691 \pm 0.142912^{\mathrm{a}}$ \\
\hline JP & $89.90142 \pm 6.342886^{\mathrm{a}, \mathrm{b}}$ & $66.87654 \pm 2.013292^{\mathrm{b}}$ \\
\hline
\end{tabular}

* Different letters in the column indicate statistical difference by the Tukey $(\mathrm{p}<0,05)$. AS = Yellow Araçá shell; AP= Yellow Araçá Pulp; CS= Big River Cherry Shell; CP= Big River Cherry Pulp; JS= Jaboticaba Shell; JP= Jaboticaba Pulp.

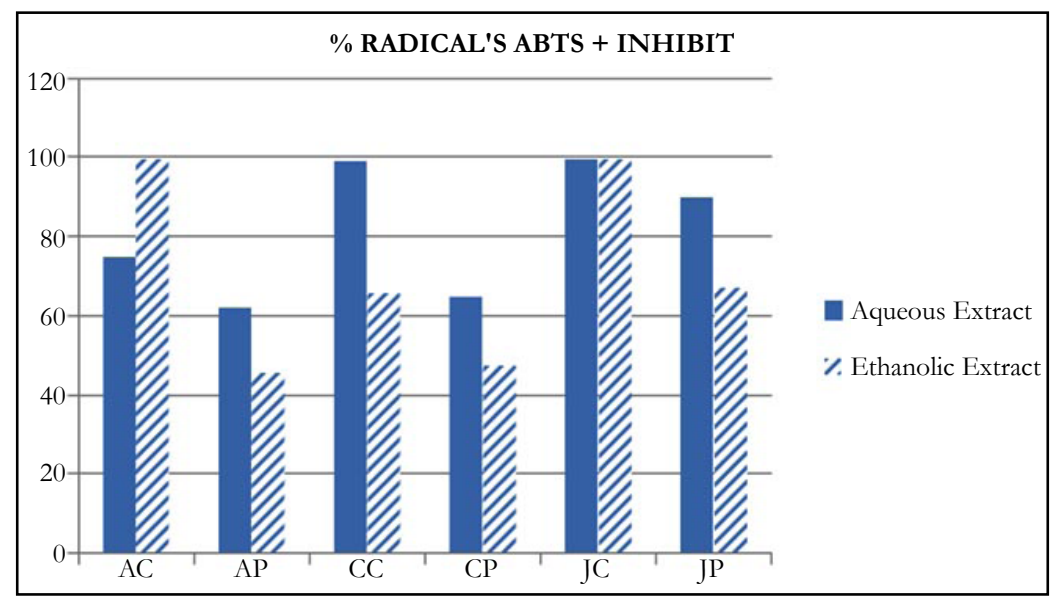


were CC (99.18615 \pm 0.329039$)$ and JC $(99.33517 \pm 0.218091)$ in aqueous extract and AC (99.59259 \pm 0.183946$)$ and JC (99.224691 $\pm 0.142912)$ in ethanolic extract.

Araújo points out significant results in relation to the entire fruit of the cherry-of-big-river [22].

According to the data obtained by the present study, it is observed that the highest antioxidant capacity of the fruit is found in the portion of the bark. For the Araçá and Jaboticaba, the AC portion (99.59259 \pm 0.183946$)$ showed a higher percentage of inhibition of the ABTS radical in ethanol solution, together with the JP portion $(66.87654 \pm 2.013292)$.

The peel of Jaboticaba proves to be a valuable natural antioxidant because of its high rate of phenolic compounds that attribute the fruit's protection by the inhibition of free radicals by their antioxidant capacity [20]. Similarly, araçá stands out for its antioxidant potential, and is a source of vitamins and minerals [21]. The data from this study corroborate with investigations that affirm that much of the beneficial compounds are in the portion of the fruit peel $[23,24]$.

The aqueous extract had a higher capacity to sequester the ABTS radical except for the AC portion. The same is observed in a study with blackberries [23].

\section{Brix and Color Grades}

Brix grades are used to evaluate the content of soluble solids contained in fruits. Generally these solids are composed of sugars, so the values obtained by the refractometer indicate the degree and sweetness of the fruit, which together with the color and acidity help in determining its maturation point and the best time to harvest $[17,25]$.

The fruits presented distinct values of ${ }^{\circ}$ Brix, differing significantly among them with higher values for jaboticaba, as can be observed in Table 3.

The color is used both to estimate the levels of food compounds and to the process of selecting new plants, since it is one of the attributes most valued by the consumer [26]. The reflectance curve observed in the RGB pattern is described in Table 4, indicating a statistically significant difference between the three fruits.

\section{Evaluation of phytochemical compounds}

The phenolic compounds are the major responsible for the antioxidant activity in fruits [24]. In order for these compounds to be considered as antioxidants and to play their biological role, they must be capable of preventing, retarding or preventing self-oxidation or oxidation mediated by free radicals at low concentrations and that the product formed after the reaction is stable [25].

Table 5 shows a higher amount of phenolic compounds in the portions of JC $(51.5953 \pm 14.5635)$, being the only result with a statistically significant difference. The bark of Jaboticaba is widely regarded as a food rich in phenolic compounds [26, 27].

Anthocyanins are water-soluble pigments, varying in red, orange and blue. As the shell of the jabuticaba was highly pigmented, a high content of this compound was already expected (1.902749 $\pm 0.161868)$, as well as the result found in related studies [26, 28], being the only result that presented a statistically significant difference.

Still in the pigment class. the evaluated chlorophyll presented higher value in the portions of JC and CC. Since the two did not differ, however, CC also did not present statistically significant differences between any of the other portions of the fruits evaluated [29].

Table 3. Soluble solids content in three native fruits of southern Brazil.

\begin{tabular}{|c|c|}
\hline Fruits & Brix Degree \\
\hline Yellow Araçá & $11.4 \pm 0.08165^{\mathrm{b}}$ \\
\hline Big River Cherry & $9.4 \pm 0.368179^{\mathrm{c}}$ \\
\hline Jaboticaba & $12.9 \pm 0.08165^{\mathrm{a}}$ \\
\hline
\end{tabular}

* Different letters in the column indicate statistical difference by the Tukey $(p<0,05)$.

Table 4. Color measurement of three native fruits from southern Brazil.

\begin{tabular}{|c|c|c|c|}
\hline & \multicolumn{3}{|c|}{ COLOR } \\
\cline { 2 - 4 } & $\mathbf{L}$ & $\mathbf{A}$ & B \\
\hline Yellow Araçá & $60.89 \pm 5.72^{\mathrm{a}}$ & $2.85 \pm 4.58^{\mathrm{b}}$ & $37.20 \pm 3.29^{\mathrm{a}}$ \\
\hline Big River Cherry & $27.66 \pm 1.46^{\mathrm{b}}$ & $13.84 \pm 0.75^{\mathrm{a}}$ & $5.11 \pm 0.96^{\mathrm{b}}$ \\
\hline Jaboticaba & $28.98 \pm 0.50^{\mathrm{b}}$ & $3.56 \pm 1.09^{\mathrm{b}}$ & $1.20 \pm 0.59^{\mathrm{c}}$ \\
\hline
\end{tabular}

* Different letters in the column indicate statistical difference by the Tukey $(\mathrm{p}<0,05)$.

$$
\mathrm{L}=\text { Luminosity; }
$$

$\mathrm{A}=\mathrm{red} /$ green coordenate $(+\mathrm{a}$ indicates red and $-\mathrm{a}$ indicates green);

$\mathrm{B}=$ yellow/blue coordenate $(+\mathrm{b}$ indicates yellow and $-\mathrm{b}$ indicates blue $)$ 
Table 5. Content of phenolic treatments, flavonoids, acidity and vitamin C.

\begin{tabular}{|c|c|c|c|c|}
\hline & $\begin{array}{c}\text { Phenolic Compounds } \\
(\mathbf{m g} \text { EAG/g) }\end{array}$ & $\begin{array}{c}\text { Flavonoids } \\
(\mathbf{m g} \text { EQ/g) }\end{array}$ & $\begin{array}{c}\text { Acidity } \\
(\mathbf{m g} / \mathbf{g} \text { acetic acid) }\end{array}$ & $\begin{array}{c}\text { Vitamin C } \\
(\mathbf{m g} / \mathbf{1 0 0 g})\end{array}$ \\
\hline AS & $0.1026 \pm 0.0001^{\mathrm{b}}$ & $0.0096 \pm 0.0005^{\mathrm{b}}$ & $12.5829 \pm 1.0462^{\mathrm{c}}$ & $6.9333 \pm 0.4784^{\mathrm{b}}$ \\
\hline AP & $0.0977 \pm 0.0003^{\mathrm{b}}$ & $0.0104 \pm 0.0011^{\mathrm{b}}$ & $12.9469 \pm 1.7166^{\mathrm{c}}$ & $10.2667 \pm 0.1247^{\mathrm{a}}$ \\
\hline CS & $0.1125 \pm 0.0007^{\mathrm{b}}$ & $0.0146 \pm 0.0013^{\mathrm{a}}$ & $17.5128 \pm 2.4893^{\mathrm{b}, \mathrm{c}}$ & $10.6000 \pm 1.6512^{\mathrm{a}}$ \\
\hline CP & $0.1053 \pm 0.0004^{\mathrm{b}}$ & $0.0105 \pm 0.0004^{\mathrm{b}}$ & $18.4775 \pm 1.6389^{\mathrm{b}}$ & $5.5667 \pm 0.5907^{\mathrm{b}, \mathrm{d}}$ \\
\hline JS & $51.5953 \pm 14.5635^{\mathrm{a}}$ & $0.0175 \pm 0.0012^{\mathrm{a}}$ & $27.1797 \pm 1.4266^{\mathrm{a}}$ & $3.3000 \pm 0.8832^{\mathrm{c}, \mathrm{d}}$ \\
\hline JP & $0.1002 \pm 0.0002^{\mathrm{b}}$ & $0.0096 \pm 0.0007^{\mathrm{b}}$ & $25.5108 \pm 0.3151^{\mathrm{a}}$ & $1.9333 \pm 0.4110^{\mathrm{c}}$ \\
\hline
\end{tabular}

* Different letters in the column indicate statistical difference by the Tukey $(\mathrm{p}<0,05)$.

AS = Yellow Araçá shell; AP = Yellow Araçá Pulp; CS = Big River Cherry Shell; CP = Big River Cherry Pulp; JS = Jaboticaba Shell; JP = Jaboticaba Pulp.

Table 6. Contents of Chlorophyll, Carotenoids and Anthocyanins.

\begin{tabular}{|c|c|c|c|}
\hline & $\begin{array}{c}\text { Total Chlorophylis } \\
(\mathbf{m g} / \mathbf{1 0 0 g})\end{array}$ & $\begin{array}{c}\text { Carotenoids } \\
(\boldsymbol{\mu g} / \mathbf{1 g})\end{array}$ & $\begin{array}{c}\text { Anthocyanins } \\
(\mathbf{m g} / \mathbf{1 0 0 g})\end{array}$ \\
\hline AS & $0.4211 \pm 0.1006^{\mathrm{b}}$ & $27363.1000 \pm 5171.8580^{\mathrm{e}}$ & $0.0104 \pm 0.0028^{\mathrm{b}}$ \\
\hline AP & $0.2620 \pm 0.0813^{\mathrm{b}}$ & $30545.6300 \pm 432.2190^{\mathrm{d}, \mathrm{e}}$ & $0.0041 \pm 0.0040^{\mathrm{b}}$ \\
\hline CS & $0.6764 \pm 0.0934^{\mathrm{a}, \mathrm{b}}$ & $144970.2000 \pm 540.7599^{\mathrm{a}}$ & $0.2906 \pm 0.1702^{\mathrm{b}}$ \\
\hline CP & $0.2219 \pm 0.0761^{\mathrm{b}}$ & $44265.1500 \pm 11551.2300^{\mathrm{b}, \mathrm{d}}$ & $0.0339 \pm 0.0121^{\mathrm{b}}$ \\
\hline JS & $1.2936 \pm 0.4476^{\mathrm{a}}$ & $54429.3500 \pm 7244.8470^{\mathrm{b}}$ & $1.9027 \pm 0.1619^{\mathrm{a}}$ \\
\hline JP & $0.2684 \pm 0.0489^{\mathrm{b}}$ & $3333,5830 \pm 908.1596^{\mathrm{c}}$ & $0.0677 \pm 0.0415^{\mathrm{b}}$ \\
\hline
\end{tabular}

* Different letters in the column indicate statistical difference by the Tukey $(\mathrm{p}<0,05)$.

AS = Yellow Araçá shell; AP = Yellow Araçá Pulp; CS = Big River Cherry Shell; CP = Big River Cherry Pulp; JS = Jaboticaba Shell; JP = Jaboticaba Pulp.

Regarding carotenoids, the CC portion presented the highest value among the results obtained $(144970.2000 \pm 540.7599)$ and showed statistically significant difference compared to all other portions.

\section{Conclusion}

The evaluation of the fruit fractions allows to conclude that the highest antioxidant activity is concentrated in the bark, mainly in Great-cherry and jaboticaba, in an aqueous medium, similar behavior when using the ethanolic medium, which resulted in higher values for peel of Yellow Araçá and Jaboticaba. For the flavonoids, higher concentrations were found in the fruit peel under study, except for the yellow Araçá pulp, similar behavior for vitamin C. The phenolic compounds were distinguished in the bark of Jaboticaba and the carotenoids in the bark of the Cherryof-the-river -great. The yellow Araçá has a higher concentration of carbohydrates than the Big River Cherry, of proteins. Considering the studies carried out in vitro, it is concluded that the native fruits demonstrate a potential capacity to assist in the protection of the organism, inhibiting the action of free radicals by the presence of their natural antioxidants, in the pulp and peel.

\section{Acknowledgment}

We thank the performance of all the staff involved in the present study, in particular the Company Embrapa Clima
Temperado-Pelotas/RS, for the transfer of the material for the analysis and elaboration of the Research; to the Laboratory of Chromatography, of the Postgraduate Course in Agroindustrial Science and Technology/Faculty of Agronomy/UFPEL; to the Department of Nutrition (FN) and Collective Health, of the Federal University of Pelotas, involved in this Project, for the support and support in the samplings, contributing in a decisive way, from the data collection to the formulation of the results, for the success and soon development.

\section{References}

[1]. Alexandre Lorini, Deborah Otero, Cristina Jansen, Bruna da Fonseca Antunes, RUI CARLOS ZAMBIAZI. Phenolic compounds in Brazilian native fruits. In: Proceedings of the Latin American Symposium on Food Science. SP, Campinas, Brasil. 2018. Available from: https://proceedings.science/ slaca/slaca-2017/trabalhos/phenolic-compounds-in-brazilian-native-fruits

[2]. World Health Organization. WHO global report on traditional and complementary medicine. 2019; May 16.

[3]. Haddadian K, Haddadian K, Zahmatkash M. A review of Plantago plant. Indian J Tradit Know.2014;13(4):681-685.

[4]. Lopes RM,Oliveira TT,Nagem TJ, Pinto AS. Flavonoids. Biotechnology Science \& Development.2010.

[5]. KÖHLER M, BRACK P. Native fruits in Rio Grande do Sul: cultivating and valuing diversity. 2016;13(2).

[6]. Lemos MRB, Zambiazi RC, Peres MSL, Pizzi GLBL. Implications of Oxidative Stress in Chronic Diseases, Benefits of Ferulic Acid to the Health and Effect of Heat Treatment on Its Antioxidant Potential.1st ed. In: Ferulic Acid: Antioxidant Properties, Uses and Potential Health Benefits. New York: Nova Science Publishers;2014.p.1-179.

[7]. Van Horn L, McCoin M, Kris-Etherton PM, Burke F, Carson JA, Champagne $\mathrm{CM}$,et al.,The evidence for dietary prevention and treatment of car- 
diovascular disease. J Am Diet Assoc. 2008 Feb 1;108(2):287-331.

[8]. Rochfort S, Panozzo J. Phytochemicals for health, the role of pulses. J Agr Food Chem. 2007 Sep 5;55(20):7981-94

[9]. Thompson HJ, Heimendinger J, Gillette C, Sedlacek SM, Haegele A, O'Neill C,et al., In vivo investigation of changes in biomarkers of oxidative stress induced by plant food rich diets. J Agric Food Chem. $2005 \mathrm{Jul}$ 27;53(15):6126-32. PubMed PMID:16029006.

[10]. Liu RH, Liu J, Chen B. Apples prevent mammary tumors in rats. J Agric Food Chem. 2005 Mar 23;53(6):2341-3. PubMed PMID: 15769178

[11]. AOAC INTERNATIONAL. Official Methods of Analysis. 21st ed. [Acessed 2019 Oct 20]. Available from: https://www.aoac.org/official-methods-of-analysis-21st-edition-2019/

[12]. HunterLab CI. L* $\mathrm{a}^{*} \mathrm{~b}^{*}$ color scale. Applications note, Virginia, USA. 1996.

[13]. Alves E, Kubota EH. Phenolic content, total flavonoids and antioxidant activity of commercial propolis samples. J Basic Appl Pharm Sci. 2013;34(1):37-41.

[14]. Rodriguez-Amaya DB. A guide to carotenoid analysis in foods. Washington: ILSI press; 2001.

[15]. Francis FJ. Analysis of anthocyanins. P Markakis, editor. Anthocyanins as food colors. New York: Academic Press;1982. p.181-207.

[16]. Funari CS, Ferro VO. Propolis analysis. Food Science and Technology. 2006 Mar; 26 (1): 171-8.

[17]. Harmut A. Chlorophylls and carotenoids:pigments of photosynthetic membranes. Methods Enzymol.1987;148:350-83.

[18]. Re R, Pellegrini N, Proteggente A, Pannala A, Yang M, Rice-Evans C. Antioxidant activity applying an improved ABTS radical cation decolorization assay. Free radical biology and medicine. 1999 May 1;26(9-10):1231-7.

[19]. Zenebon O, Pascuet NS, Tiglea P. Analytical Standards of the Adolfo Lutz Institute. 4th ed. Chemical and physical methods for food analysis. São Paulo: IMESP; 2008. \%2C5\&q=Analytical+Standards+of+the+Adolfo+Lu tz+Institute\&btnG=

[20]. Zambiazi RC. Physical-chemical analysis of food. Pelotas: UFPel publishing company. 2010

[21]. Vanin CD. Yellow Araçá : antioxidant activity, nutritional composition and application of cereal bars. Master's Dissertation, Federal Technological University of Paraná - Londrina. 2015.

[22]. Araujo VF, Bialves TS, Vizzotto M, Krolow ACR,Ferri NML,Silveira CA. Functional properties and physico-chemical quality of the cherry-of-riogrande (eugenia involucrata dc.) In natura and processed in the form of jelly. In: FOOD SECURITY SYMPOSIUM. Gramado. SBCTA-RS Regional.2012.

[23]. Araujo LF, Moreira JJS, Santos BS, Oliveira JR, AM NUNES. Evaluation of the potential of the jabuticaba bark meal (Plinia Caulifora) to be used by the food industry: anthocyanins and antioxidant capacity. Brazilian Congress of Food Science and Technolog. 2016:25.

[24]. Oliveira FC. Extracts of jabuticaba bark: phenolic compounds and antibacterial activity. Lavras: UFLA. 2016.

[25]. Neri-Numa IA, Carvalho-Silva LB, Morales JP, Malta LG, Muramoto MT, Ferreira JE, de Carvalho JE, Ruiz AL, Junior MR, Pastore GM. Evaluation of the antioxidant, antiproliferative and antimutagenic potential of araçáboi fruit (Eugenia stipitata Mc Vaugh-Myrtaceae) of the Brazilian Amazon Forest. Food research international. 2013 Jan 1;50(1):70-6.

[26]. CELANT V, Braga GC, Vorpagel JA, Salibe AB. Phenolic composition and antioxidant capacity of aqueous and ethanolic extracts of blackberries. Revista Brasileira de Fruticultura. 2016;38(2).

[27]. Heim KE, Tagliaferro AR, Bobilya DJ. Flavonoid antioxidants: chemistry, metabolism and structure-activity relationships. The Journal of nutritional biochemistry. 2002 Oct 1;13(10):572-84.

[28]. Giordano D, Locatelli M, Travaglia F, Bordiga M, Reyneri A, Coïsson JD, Blandino M. Bioactive compound and antioxidant activity distribution in roller-milled and pearled fractions of conventional and pigmented wheat varieties. Food chemistry. 2017 Oct 15;233:483-91.

[29]. Lima A. Chemical characterization and antioxidant activity of jabuticaba's fruit and its fraction (Myrciaria cauliflora (Mart.) O. Berg. UFLA;2009. 